\title{
Quantitative Assessment of Yam Based Farmers' Perception on Climate Change in Edo State, Nigeria
}

\section{Jerumeh Elijah Gift, Okoruwa Victor Olusegun, Sowunmi Fatai Abiola, Idiaye Chuks Onyeka}

Department of Agricultural Economics, University of Ibadan, Ibadan, Nigeria

\section{Email address:}

fasowunmi@live.co.uk (S. F. Abiola)

\section{To cite this article:}

Jerumeh Elijah Gift, Okoruwa Victor Olusegun, Sowunmi Fatai Abiola, Idiaye Chuks Onyeka. Quantitative Assessment of Yam Based Farmers' Perception on Climate Change in Edo State, Nigeria. International Journal of Agricultural Economics.

Vol. 3, No. 3, 2018, pp. 53-64. doi: 10.11648/j.ijae.20180303.13

Received: March 7, 2018; Accepted: March 26, 2018; Published: June 25, 2018

\begin{abstract}
Using data collected from 250 yam based farming households in the Edo state, Nigeria, the study demonstrated the quantitative assessment of yam based farmers' perception on climate change. Farmers' perceptions on three important climatic variables in agricultural production (temperature, rainfall and wind intensity) were quantified using a quasi-arbitrary ordinal weighting system. The results revealed first demand indices for temperature, rainfall and wind intensity as $0.87,0.38$ and 0.84 respectively while the first supply indices for temperature, rainfall and wind intensity were $0.27,0.22$ and 0.14 respectively. The study indicated significant increase and decrease in temperature and rainfall respectively. The study also affirmed that climate change contributed significantly to reduction in yam production in the study area. The study recommends the need for programmes geared towards providing farmers with effective adaptation strategies which would help provide a buffer against adverse climatic conditions.
\end{abstract}

Keywords: Perception, Climate Change, Quasi-arbitrary Ordinal Weighting System, Demand and Supply Indices

\section{Introduction}

Climate change is emerging as the most important environmental problem facing modern society. Increases in atmospheric stocks of greenhouse gases (GHG), including carbon dioxide $\left(\mathrm{CO}_{2}\right)$, methane $\left(\mathrm{CH}_{4}\right)$ and nitrous oxide $\left(\mathrm{N}_{2} \mathrm{O}\right)$, due to human activities have been linked to global climate change [8]. The fourth assessment report of the IPCC in 2007 [8] emphasized that there will be changes in the frequency and intensity of some weather events and extreme climate events which will likely challenge human and natural systems much more than gradual changes in mean conditions. According to this report, it is virtually certain (more than 99\% probability of occurrence) that most land areas will have warmer and fewer cold days and nights. It is also very likely that most areas (between 90 to $99 \%$ probability of occurrence) will have warmer temperature, more frequent heat waves and heavy precipitation events. More drought, tropical cyclone, and incidence of extreme high sea level are also likely.

Agriculture is particularly vulnerable to climate change due to its dependence on natural weather patterns and climate cycles for its productivity. There is a growing literature focused on predicting and quantifying the impact of climate change on agricultural systems in many areas around the world. A few degrees of warming will generally increase temperate crop yields while in the tropics, yields of crops near to their maximum temperature tolerance and dry land crops will decrease. A large decrease in rainfall would have even greater adverse effect on yields. In addition, degradation of soil and a decrease in water resources resulting from climate change are likely to have negative impacts on global agriculture [7].

However, with adaptation, crop yields will likely be less affected by climate change. Quantifying the economic impact and assessing perception of climate change on agriculture is receiving increasing attention in the literature. It has been estimated that a 2.5 degrees $\left({ }^{\circ} \mathrm{C}\right)$ or more temperature increase would cause a decline in crop yield and prompt food prices to increase because growth in global food demand is faster than expansion of global food capacity [12].

Nigeria is not at the cutting edge to cope with sudden climate change shocks, the country is dependent on foreign support and therefore any adverse climate change will have 
catastrophic effect on food security in the country. For Nigeria, climate change poses great challenges to livelihoods and the economic development of the people. This is because, after petroleum and its products, the country depends on agriculture as a major engine for economic growth and development [14]. Like other developing countries, the challenge of climate change and global warming is enormous in Nigeria due to widespread poverty. Consequently, a better understanding of farmers' perceptions regarding long-term climatic changes, its effect on agricultural production and current adaptation measures will be important to inform policy for future successful adaptation of the agricultural sector in the country.

Climate change has affected the yield of a lot of food crops in Nigeria particularly yam production. It is also evident that yam production in Nigeria has declined over the past 40 years from 27 million tonnes per annum in 1961 to 6.7 million tonnes per annum in 2001 [6]. This decrease can however be attributed to a number of factors such as fungal diseases, plant viruses, declining soil fertility and stress caused by climate change [1]. This decline in average yield per hectare has been rather drastic dropping from $14.9 \%$ in $1986-1990$ to $2.5 \%$ in 1999 [5]. Because of this decline, Bill and Melinda Gates foundation recently released $\$ 12.2$ million for the purpose of increasing yam production both in yield and net output by $40 \%$ in Ghana and Nigeria. The yam project was tagged "Yam Improvement for Income and Food Security and Food Security in West Africa " (YIIFSWA) [1].

The perception of farmers to climate change variable characteristics and the effect, however, affect the strategies to be adopted for yam production in order to achieve YIIFSWA objectives. In addition to the above, some government agencies have been working assiduously to increase the consciousness of the public on climate change and its effect, however, more efforts need to be made in order to sensitize and prepare quite a sizeable number of individuals who are still oblivious of the changing climate around them.

The paper is aimed at analyzing the perception of yam based farmers on climatic change in Edo state. Specifically, the study concentrated on three climatic variables, namely: air temperature, rainfall and wind intensity which are the three important climatic variables not only in yam production but in crops generally. The study is also an effort to measure and quantify the perception of yam based farmers on climatic change (rainfall, air temperature and wind intensity) in Edo state. While there have been comments here and there on the decline and irregularity in annual rainfall, and increase in air temperature; this study is a way of presenting the perceptions of yam based farmers on these important climatic variables empirically as well as identifying various coping strategies being adopted to ameliorate the negative effect of climatic change on yam production in the study area.

\section{Methodology}

The study was carried out in Edo State. The state lies roughly between longitude $06^{\circ} 04^{\prime} \mathrm{E}$ and $06^{\circ} 43^{\prime} \mathrm{E}$ and latitude $05^{\circ} 44^{\prime} \mathrm{N}$ and $07^{0} 34^{\prime} \mathrm{N}$. Edo is geographically located in central southern Nigeria which is bounded in the North and East by Kogi State, in the south by Delta State and in the west by Ondo State. The Northern part of Edo State shares the same savannah conditions with Northern Nigeria. The South, Central and part of the North also share the rain forest conditions with the rest of Southern Nigeria. Edo State has a tropical climate characterized by two distinct seasons: the wet and dry seasons. The wet season occurs between April and October with a break in August, and an average rainfall ranging from $150 \mathrm{~cm}\left(59^{\prime \prime}\right)$ in the extreme north of the State to $250 \mathrm{~cm}\left(98^{\prime \prime}\right)$ in the south. The dry season lasts from November to April with a cold harmattan spell between December and January. There are eighteen local government areas in Edo state. Edo state is known for the cultivation of maize, groundnut, guinea corn, soybeans, cassava, yam, vegetables, fruits, oil palm, cocoa, rubber, pharmaceutical herbs and ornamental trees, among others.

\subsection{Data}

The study utilized primary data. The primary data were obtained from respondents in the study area through the use of structured questionnaire. The study considered 250 yam based farmers in the study area. The information collected encompassed socio-economic characteristics of respondents. These are age, sex, marital status, household size, farming experience and years of formal education as well as perception on climatic variables and methods of adaptation to climate change. A multistage (three - stage) sampling procedure was employed to sample yam farmers from the three agro ecological zones (the north, the south and the central). In the first stage of sampling, Edo north and Edo central were randomly selected from the three agro ecological zones. From the selected zones, ten local government areas known for yam production were purposively selected from a total of 18 local government areas in the state (second stage sampling). In each local government, a village was randomly selected based on the reasonably high number of yam based farmers in the state representing the third stage of sampling. The last stage involved a random selection of 25 farmers from the chosen villages and this gave a total of 250 farmers. This was necessary for equal representation of the yam based farmers in the selected villages.

\subsection{Method of Analysis}

The descriptive statistics and index from quasi ordinal weighting matrix system reflecting farmers' perceptions were used to achieve the objective of the study. The descriptive analysis involved the use of percentages and charts to show the various perception of farmers based on the observed change in climatic variables as well as the corresponding effect on yam production. Also, descriptive statistics was used to analyze the socio-economic characteristics of respondents and to profile the various adaptation strategies employed by yam based farmers to mitigate the adverse 
effect of climate change in the study area.

Following Reed et al. (1991) [13], the quasi-arbitrary ordinal weights were used to assess and quantify farmer's perception. This approach uses a relatively simple index that provides an indication of how well certain climatic characteristics meet farmers' perception. The implementation involves application of quasi-arbitrary ordinal weights in which farmers rank the perception of climatic parameters such as air temperature, wind intensity and precipitation. Reed et al. (1991) showed that by choosing weights meeting certain conditions, the proposed indices are robust, and when calculated under different sets of weights, these indices are highly correlated. Each farmer was asked to judge each attribute along two scales: First, how they ranked the change in the selected climatic variables (increased, stay the same, decrease) and second, their perception of the effect of the change in climatic variables on yam production (very severe, severe and not severe) [13].

For instance, if a farmer perceives that the effect of climate change is very severe, it implies a situation of crop failure to germinate, crop loss to erosion and spoilage of yam seeds, severe explains a situation of disease and pest infestation while not severe portrays reduction in crop yield and destruction of stakes. Thus for $\mathrm{N}$ farmers, each ranking the characteristics according to their observed changes and resultant effect on yam production, the response matrix is as shown in Table 1 below:

Table 1. Response matrix.

\begin{tabular}{lllll}
\hline Farmers & \multicolumn{2}{l}{ Observed change in climatic variables } & $\begin{array}{l}\text { Row } \\
\text { total }\end{array}$ \\
\cline { 2 - 4 } Perception & Increase & Constant & Decrease & $\mathrm{r}_{1}$ \\
\hline Very severe & $\mathrm{n}_{11}$ & $\mathrm{n}_{12}$ & $\mathrm{n}_{13}$ & $\mathrm{r}_{2}$ \\
Severe & $\mathrm{n}_{21}$ & $\mathrm{n}_{22}$ & $\mathrm{n}_{23}$ & $\mathrm{r}_{3}$ \\
Not severe & $\mathrm{n}_{31}$ & $\mathrm{n}_{32}$ & $\mathrm{n}_{33}$ & \\
Column total & $\mathrm{c}_{1}$ & $\mathrm{c}_{2}$ & $\mathrm{c}_{3}$ & \\
\hline
\end{tabular}

Where:

$$
\begin{aligned}
& n_{11}+n_{12}+n_{13}=r_{1} \\
& n_{11}+n_{21}+n_{31}=c_{1}
\end{aligned}
$$

Each entry in the matrix in Table $1\left(n_{i j}\right)$, represents the number of farmers who ranked a particular attribute based on their perception of its change, $j$, and its effect on yam production, $i$. The bottom row entries, $\mathrm{c}_{\mathrm{j}}$, are the total number of farmers who ranked the climatic variable according to the change observed. The far right column entries, $r_{i}$, are the total number of farmers who ranked the effect of the observed change on yam production as very severe, severe or not severe. Given the above, the following must hold.

$$
\sum c_{j}=\sum r_{j}=\sum \sum n_{i j}=N
$$

The weighting matrix is presented in Table 2 . The far right column in the table indicates the row weights, s. These are the weights assigned to the effect of the change in climatic variables on crop production. The bottom row shows the demand weights, d, assigned to farmers' perception of the change in a particular climatic variable. Each cell in the matrix is derived as:

$$
w_{i j}=s_{i} d_{j}
$$

Reed et al. (1991) [13] proposed certain restrictions be imposed on the weights, so the following inequalities hold:

$$
w_{1 j}>w_{2 j}>w_{3 j} \text { for all } j
$$

The above inequality implies that regardless of the extent of change in climatic parameter, the more adversely the farmer perceives the effect of the change in the climatic parameter under consideration, the higher the weight is.

Table 2. Weighting matrix 1

\begin{tabular}{lllll}
\hline & Increase & Stay the same & Decrease & Supply weight \\
\hline Very severe & $\mathrm{w}_{11}$ & $\mathrm{w}_{12}$ & $\mathrm{w}_{13}$ & $\mathrm{w}_{23}$ \\
Severe & $\mathrm{w}_{21}$ & $\mathrm{w}_{22}$ & $\mathrm{w}_{33}$ & $\mathrm{~s}_{2}$ \\
Not severe & $\mathrm{w}_{31}$ & $\mathrm{w}_{32}$ & $\mathrm{~d}_{3}$ & $\mathrm{~d}_{2}$ \\
Demand weight & $\mathrm{d}_{1}$ & $\mathrm{~d}_{2}$ & & $\mathrm{~s}_{3}$ \\
\hline
\end{tabular}

$w_{1 i}>w_{2 i}>w_{3 i}>0$ for all i which is rated very severe or severe

Inequality condition in Eq. (4) states that whenever the perceived effect of the change in a climatic parameter is rated very severe or severe, the weight should be positive and it decreases in value as the change in the climatic variable decreases.

$$
w_{1 i}<w_{2 i}<w_{3 i}<0 \text { for all } \mathrm{i} \text { which is rated not severe }
$$

Inequality Eq. (5) implies that weights for the effect rated as not severe should be negative and increasing as the change in the climatic variable reduces.

The above inequalities imply the following restrictions are established when constructing the supply and demand weights:

$$
\begin{array}{r}
s_{1}>s_{2}>0>s_{3} \\
d_{1}>d_{2}>d_{3}>0
\end{array}
$$

All demand weights, $d_{j}$, are positive, while the supply weight for a climatic characteristic ranked as not severe is negative. The above weighting scheme ensures that the highest (lowest) weights will be given to those observation considered very severe or severe (not severe).

Given the response weighting matrices, the three following indexes were calculated.

$$
D=\frac{1}{d_{1} N} \sum_{j=1}^{3} d_{j} c_{i}
$$


The Demand Index (D) is a measure of how farmers perceived the change in particular climatic characteristic. A value of 1 indicates that all farmers perceive an increase in the climatic variable under consideration. If not, the minimum value of the index will be calculated as $\left(d_{3} / d_{1}\right)>0$, and is attained when all farmers perceive a decrease in the climatic variable of interest.

$$
\mathrm{S}=\frac{1}{\mathrm{~S}_{1} N} \sum_{\mathrm{j}=1}^{3} \mathrm{~s}_{\mathrm{j}} \mathrm{r}_{\mathrm{i}}
$$

The Supply Index (S) is a measure of the perception of farmers on how severe a characteristic affects crop production. A maximum value of 1 indicates that all farmers perceive the effect of a characteristic observed as being very severe. The minimum value of the index will be calculated as $\left(\mathrm{s}_{3} / \mathrm{s}_{1}\right)<0$, and this depend on the weight chosen. The minimum value will be attained if all farmers perceive the effect of the characteristic as not severe.

$$
A=\frac{1}{W_{11} N} \sum_{j=1}^{3} \sum_{i=1}^{3} w_{i j} n_{i j}
$$

The Attainment index (W) provides a measure of how well farmers' perceptions of the observed climatic variable characteristics match farmers' perceptions of how severe the observed effect is observed. The maximum value carried by $\mathrm{A}$ is 1 , and implies a perfect match. In such a situation, all farmers rank the observed change in climatic variable as increase and rank the observed effect as very severe. The minimum value of the index depends on the Supply weights, $\mathrm{Si}$, chosen, and is calculated to be

$$
S_{3} / S_{1}<0
$$

It is essential to ascertain consistency and correctness of the weights assigned for computation. Two or more weights should be assigned for this purpose. Hence, to test the robustness of the results with respect to the set of weights chosen, following the suggestion of Reed et al. (1991) [13], the results of the attainment index using the different combinations of weight were compared using Pairwise and Spearman rank correlation coefficients for each set. The Spearman correlation coefficients measure the consistency in ordering the scores, while the Pairwise correlation coefficients measure the linear relationship between the different scores. The purpose of these correlation coefficients is to show the level of significance, degree of robustness and confidence in the results.

\section{Results and Discussion}

The study revealed that $87.6 \%$ of the households were headed by male (see figure 1 below) while $12.45 \%$ were headed by female. Also, $45.2 \%$ of the head of households were above 50 years. The percentage of household heads within the age bracket of $31-40$ years was $18.8 \%$ (see table 3 below). The average household size in the study area was 7.7. Specifically, the result showed that $59.2 \%$ of the respondents had household size ranging from 5-10 while $20.4 \%$ of the respondents had household sizes ranging from $1-4$ and above 10 respectively.

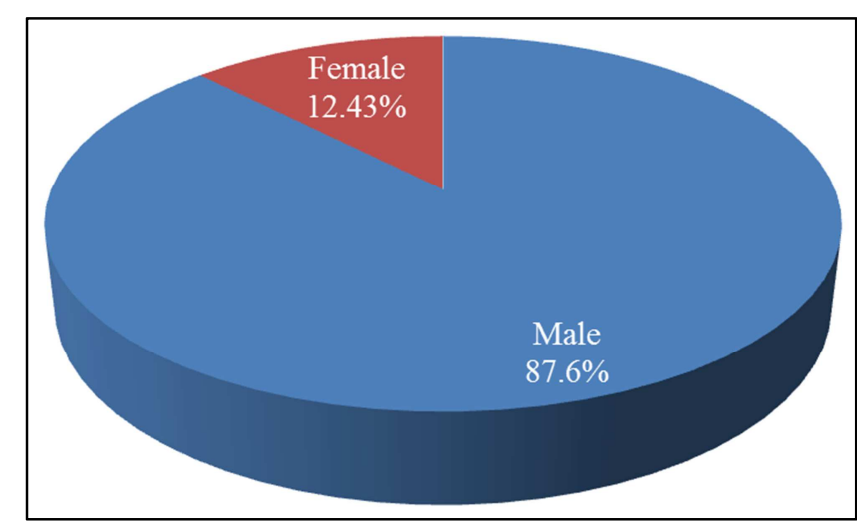

Source: Computed from field survey (2012).

Figure 1. Gender Distribution of Head of Households.

The average year of formal education attended by respondents was 8.0 years. The result below (see table 3) shows that $34.8 \%$ of the respondents had $1-6$ years of formal

\begin{tabular}{|c|c|c|c|}
\hline & Characteristic & Frequency & Percentage (\%) \\
\hline \multirow[t]{3}{*}{1.} & Sex of Household head & & \\
\hline & Male & 219 & 87.60 \\
\hline & Female & 31 & 12.43 \\
\hline \multirow[t]{7}{*}{2.} & Age (year) of Household Head & & \\
\hline & Less than 30 & 26 & 10.40 \\
\hline & $31-40$ & 47 & 18.80 \\
\hline & $41-50$ & 64 & 25.60 \\
\hline & Above 50 & 115 & 45.20 \\
\hline & Average: 48.4 & & \\
\hline & Standard Deviation: 13.03 & & \\
\hline \multirow[t]{7}{*}{3.} & Year of Formal Education & & \\
\hline & 0 & 49 & 19.50 \\
\hline & $1-6$ & 87 & 34.80 \\
\hline & $7-12$ & 80 & 32.00 \\
\hline & Above 12 & 34 & 16.83 \\
\hline & Average: 8.0 , & & \\
\hline & Standard Deviation: 5.74 & & \\
\hline \multirow[t]{6}{*}{4.} & Household size & & \\
\hline & Less than or equal 4 & 55 & 20.40 \\
\hline & $5-10$ & 140 & 59.20 \\
\hline & Above 10 & 55 & 20.40 \\
\hline & Average: 7.7 & & \\
\hline & Standard Deviation: 4.4 & & \\
\hline
\end{tabular}
education while $19.5 \%$ had no formal education.

Table 3. Socioeconomic Characteristics of Sampled Farmers.

Source: Computed from field survey (2012).

Figure 2 below presents the distribution of farmers' perceptions on climatic change based on the three identified climatic variables (air temperature, rainfall and wind intensity). As indicated in the figure, $78 \%$ of the farmers in study area were aware of continuous increase in air temperature while 67 percent of farmers perceived a steady decline in precipitation over the years. The farmers' perceptions on wind intensity show that $57.2 \%$ and $22.4 \%$ of the respondents observed an increase and decrease in wind 
intensity respectively. These results agree with $[14,10,2,11]$.

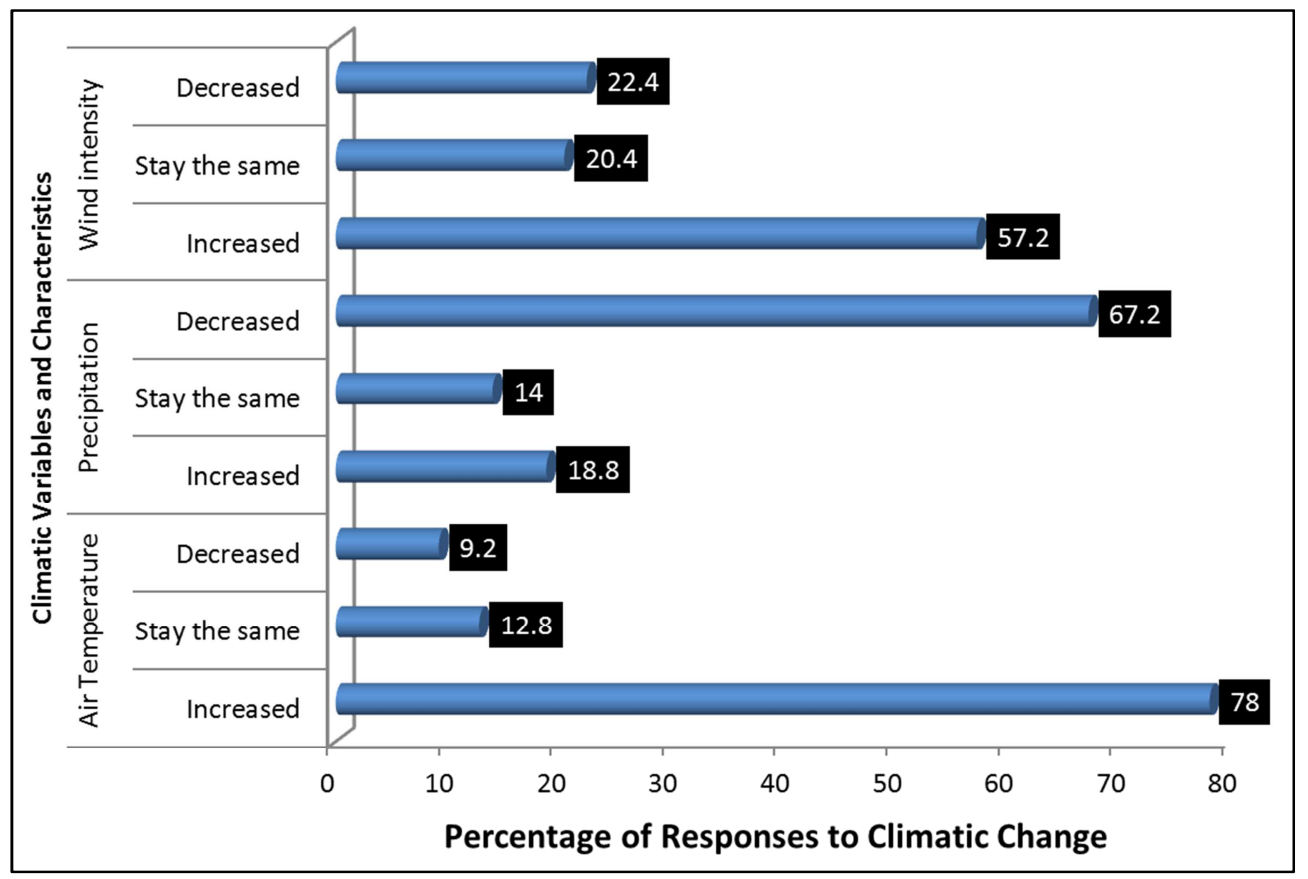

Source: Computed from field survey (2012)

Figure 2. Distribution of Farmers' Perception on Climatic Change.

Based on the perceptions expressed by farmers on air temperature, rainfall and wind intensity which are important climatic variables in crop production, table 3 below shows the of effects of these farmers' perceptions on yam production. The severity of effect that corresponds to the change in a given climatic variable is ranked by the sampled farmers as very severe, severe and not severe.

Table 4. Farmers' Perceptions on the effect of climatic change on yam Production

\begin{tabular}{lll}
\hline Climatic variables & Effects & Percentages \\
\hline \multirow{3}{*}{ Air Temperature } & Very severe & 28.80 \\
& Severe & 44.00 \\
& Not severe & 31.20 \\
\multirow{3}{*}{ Precipitation } & Very severe & 32.40 \\
& Severe & 24.40 \\
& Not severe & 43.20 \\
Wind intensity & Very severe & 18.00 \\
& Severe & 35.60 \\
& Not severe & 46.40 \\
\hline
\end{tabular}

Source: Computed from field survey (2012).

The table shows that majority of the farmers ranked the effect of the change in both precipitation and wind change as not severe $(43.2 \%$ and $46.4 \%$ respectively) while air temperature was ranked as severe $(44.0 \%)$ on yam production. This is an indication that the effects of rainfall and wind intensity were not very pronounced. Many factors might have contributed to these perceptions, among which are the adoptions or non adoption of coping strategy as well as the type of coping strategy being used where adoption is taking place. Table 4 below shows the adaptation methods or strategies employed by the sampled farmers. The table shows that majority of the farmers perceived at least one change in climatic attributes. However, about 0.136 (proportion) of the sampled farmer did not adopt any adaptation measure to mitigate the negative effect of climate change. This may be attributed to lack of awareness on the part of concerned farmers to different coping strategies or the unwillingness to change because they perceived that each change comes with own challenges and as such farmers tend to rationalize input.

(i). Estimation of farmers' perception of climate change using quasi-arbitrary method

Using Equations (6) and (7), three sets of weights were used to calculate the indices (demand, supply and attainment indices) for the climatic variables- temperature, rainfall and wind intensity). Also, the robustness of the results obtained for the above indices was verified. These weights including the response matrix are shown in appendices 1 and 2 .

Table 5. Demand indices.

\begin{tabular}{lllll}
\hline & Indices & Temperature & Precipitation & Wind intensity \\
\hline 1. & Max value & 1 & 1 & 1 \\
& Index & 0.87 & 0.38 & 0.84 \\
& Min value & 0.25 & 0.20 & 0.50 \\
2. & Max value & 1 & 1 & 1 \\
& Index & 0.92 & 0.62 & 0.73 \\
& Min value & 0.5 & 0.5 & 0.25 \\
3. & Max value & 1 & 1 & 1 \\
& Index & 0.92 & 0.63 & 0.82 \\
& Min value & 0.20 & 0.5 & 0.40 \\
\hline
\end{tabular}

According to Reed et. al, (1991) [13], a value of 1, which is the highest value obtainable, indicates that all the farmers' perceived that the climatic variable under consideration has 
increased while the minimum value shows that all the farmers perceive a decrease. From the above, the first demand index is 0.87 and since this value is quite high (close to 1), it implies that majority of the farmers (not all) perceived an increase in temperature. This result agrees with studies carried out by $[2,14]$. The demand indices 2 and 3 were included to test for consistency. Given the above values and following the conditions given by [13], the same conclusion can be drawn that majority of the farmers perceived an increase in temperature and this therefore shows that the results are consistent across all the three weighting schemes. For precipitation, as shown in set 1 , the demand index of 0.38 with a minimum value of 0.20 implies that a greater part of the sampled farmers perceived a decrease in precipitation. The same conclusion can be drawn from the second and third indexes. Considering wind intensity, the first demand index has a value of 1 which indicates that all the farmers' perceive that wind intensity has increased while the minimum value $(0.50)$ shows that all the farmers perceive a decrease in wind intensity. Since the value $(0.84)$ is quite high (closer to 1), it can be concluded that majority of the farmers perceived an increase in wind intensity. The same conclusion can be deduced for the second and third indices.

The supply indices which measure the extent of severity of the effect of the change in climatic variables on yam production are shown in table 6 below. The extent of severity of the change was ranked by each farmer as severe, not severe and very severe.

Table 6. Supply indices.

\begin{tabular}{lllll}
\hline & Indices & Temperature & Precipitation & Wind intensity \\
\hline 1. & Max value & 1 & 1 & 1 \\
& Index & 0.27 & 0.221 & 0.144 \\
& Min value & -0.2 & -0.33 & -0.33 \\
2. & Max value & 1 & 1 & 1 \\
& Index & 0.29 & 0.29 & 0.09 \\
& Min value & -0.33 & -0.20 & -0.33 \\
3. & Max value & 1 & 1 & 1 \\
& Index & 0.34 & 0.22 & 0.22 \\
& Min value & -0.17 & -0.33 & -0.17 \\
\hline
\end{tabular}

For temperature, as shown in the table above, the first supply index is 0.27 . Compared to the maximum value which is 1 (implying that all farmers perceived the effect of temperature change as very severe), the supply index is in between the maximum value (1) and the minimum value (-0.2). By implication, it can be said that most of the sampled farmers perceived the effect of the change in precipitation as severe. The same conclusion can be drawn for the second and third indexes. For precipitation, the first supply index, as shown in the table above, is 0.221 and having a minimum value of -0.33 . Following the conditions given by [13], it therefore implies that majority of the farmers in the sampled area perceived that the effect of precipitation on yam production was severe. The same conclusion was drawn for the second and third index. The result in table 6 also shows that the supply index for wind intensity is 0.144 with a minimum value equal to -0.33 . It therefore implies that not all farmers ranked the effect of the increase in wind intensity as not severe. The same conclusion was reached for the second and third indexes.

The attainment matrix presented in table 7 provides a measure of how well farmers' perceptions of the observed change in the climatic variables match farmers' perception of how severe the observed effect is.

Table 7. Attainment matrix.

\begin{tabular}{llll}
\hline Indices & Temperature & Precipitation & Wind intensity \\
\hline Max & 1 & 1 & 1 \\
Index & 0.24 & 0.224 & 0.12 \\
Min & -0.2 & -0.33 & -0.33 \\
\hline
\end{tabular}

The table above shows attainment matrix for temperature, precipitation and wind intensity respectively. For temperature, the attainment index is 0.24 and this denotes that there is no perfect match. This implies that not all farmers ranked the observed change in temperature as increase and not all farmers ranked the effect of the change as very severe. Also, since the attainment value is not equal to the minimum value $(-0.2)$, it shows that not all the farmers ranked the observed change as decrease and ranked the effect of the observed change as not severe. This implies that not all the farmers' rankings were the same; there were variations in their perceptions of the change in the temperature and its corresponding effect on yam production. For precipitation, the minimum value of the attainment index depends on the supply weights, $\mathrm{s}_{\mathrm{i}}$, given, and it is calculated to be $\left(\frac{s_{3}}{s_{1}}\right)<0$. From the above calculation, the value is -0.33 . Given that the attainment index is 0.224 , it denotes that there is no perfect match. In such a situation, not all farmers ranked the observed change in precipitation as increase and ranked the effect of the observed change in precipitation as very severe. For wind intensity, since the attainment index is not equal to 1 or the minimum value $\left(\frac{s_{3}}{s_{1}}\right)=-0.33$, it implies that there is no perfect match between the ranking of the observed change in wind intensity and its related effect. This means that not all the farmers ranked the observed change in wind as increase and very severe and not all farmers ranked their perception on wind change as decrease and not severe. The implication of this result is that farmers' perceptions on wind change are varied and are not concentrated in a particular ranking of wind intensity attribute or characteristic.

(ii). Robustness of the indices

Using equations (6) and (7), four sets of weights were used to calculate the indices and the robustness of the results verified. The indices are said to be robust if reasonable changes in one or both sets of marginal weights do not cause major changes in the rankings given by the indices. This was examined by using 8 idealized $3 \times 3$ response matrices from which demand, supply, and attainment indices were calculated. The response matrices used are given in Appendices $13-20$. The sets of demand and supply weights are given in table 8 . 
Table 8. Supply and demand weights used in robustness analysis.

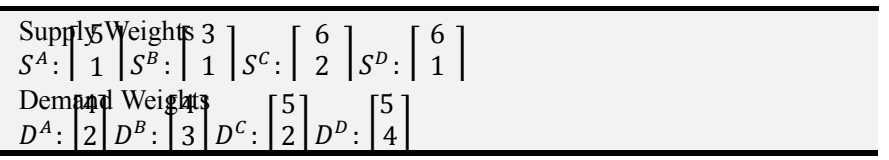

This study examined 4 sets of demand weights and 4 sets of supply weights. It follows that the weight combination given by $\mathrm{D}^{\mathrm{A}}$ and $\mathrm{S}^{\mathrm{B}}$ is referred to as $\mathrm{W}^{\mathrm{AB}}$, and so on. Result of the attainment indices using the different combinations of weights were compared using Pairwise and Spearman correlation coefficients.

Table 9. Correlations between attainment scores by different weighting formulae.

\begin{tabular}{|c|c|c|c|c|c|c|c|c|c|c|c|c|c|c|c|c|}
\hline & $\mathbf{W}^{\mathbf{A A}}$ & $\mathbf{W}^{\mathbf{A B}}$ & $\mathbf{W}^{\mathbf{A C}}$ & $\mathbf{W}^{\mathbf{A D}}$ & $\mathbf{W}^{\mathbf{B A}}$ & $\mathbf{W}^{\mathrm{BB}}$ & $\mathbf{W}^{\mathrm{BC}}$ & $\mathbf{W}^{\text {BD }}$ & $\mathbf{W}^{\mathrm{CA}}$ & $\mathbf{W}^{\mathrm{CB}}$ & $\mathbf{W}^{\mathrm{CC}}$ & $\mathbf{W}^{\mathrm{CD}}$ & $\mathbf{W}^{\mathbf{D A}}$ & $\mathbf{W}^{\mathrm{DB}}$ & $\mathbf{W}^{\mathrm{DC}}$ & $\mathbf{W}^{\mathrm{DD}}$ \\
\hline $\mathrm{W}^{\mathrm{AA}}$ & 1 & 0.97 & 1.00 & 0.97 & 0.98 & 0.96 & 0.56 & 0.96 & 0.99 & 0.98 & 0.97 & 0.97 & 1.00 & 0.97 & 1.00 & 0.97 \\
\hline $\mathrm{W}^{\mathrm{AB}}$ & 0.99 & & 0.95 & 0.99 & 0.94 & 0.98 & 0.56 & 0.97 & 0.94 & 0.99 & 0.90 & 0.98 & 0.98 & 1.00 & 0.96 & 0.99 \\
\hline $\mathrm{W}^{\mathrm{AC}}$ & 0.99 & 0.98 & & 0.94 & 0.98 & 0.94 & 0.55 & 0.94 & 0.99 & 0.96 & 0.99 & 0.95 & 0.99 & 0.94 & 1.00 & 0.95 \\
\hline $\mathrm{W}^{\mathrm{AD}}$ & 0.88 & 0.92 & 0.85 & & 0.92 & 0.96 & 0.52 & 0.97 & 0.93 & 0.98 & 0.89 & 0.98 & 0.97 & 0.99 & 0.95 & 1.00 \\
\hline $\mathrm{W}^{\mathrm{BA}}$ & 0.98 & 0.96 & 0.99 & 0.81 & & 0.97 & 0.65 & 0.97 & 1.00 & 0.97 & 0.99 & 0.97 & 0.98 & 0.94 & 0.98 & 0.95 \\
\hline $\mathrm{W}^{\mathrm{BB}}$ & 0.99 & 1.00 & 0.98 & 0.92 & 0.96 & & 0.66 & 0.99 & 0.96 & 1.00 & 0.92 & 0.98 & 0.97 & 0.99 & 0.96 & 0.98 \\
\hline $\mathrm{W}^{\mathrm{BC}}$ & 0.36 & 0.38 & 0.38 & 0.34 & 0.40 & 0.38 & & 0.64 & 0.61 & 0.61 & 0.59 & 0.60 & 0.58 & 0.58 & 0.58 & 0.57 \\
\hline $\mathrm{W}^{\mathrm{CA}}$ & 0.98 & 0.96 & 0.99 & 0.81 & 1.00 & 0.96 & 0.40 & 0.93 & & 0.96 & 0.99 & 0.97 & 0.99 & 0.94 & 0.99 & 0.95 \\
\hline $\mathrm{W}^{\mathrm{CB}}$ & 0.99 & 1.00 & 0.98 & 0.92 & 0.96 & 1.00 & 0.38 & 0.99 & 0.96 & & 0.93 & 0.99 & 0.99 & 1.00 & 0.97 & 0.99 \\
\hline $\mathrm{W}^{\mathrm{CC}}$ & 0.98 & 0.96 & 0.99 & 0.81 & 1.00 & 0.96 & 0.40 & 0.93 & 1.00 & 0.96 & & 0.93 & 0.97 & 0.90 & 0.98 & 0.91 \\
\hline $\mathrm{W}^{\mathrm{CD}}$ & 0.95 & 0.99 & 0.95 & 0.93 & 0.93 & 0.99 & 0.40 & 1.00 & 0.93 & 0.99 & 0.93 & & 0.98 & 0.98 & 0.96 & 0.99 \\
\hline $\mathrm{W}^{\mathrm{DA}}$ & 1.00 & 0.99 & 0.99 & 0.88 & 0.98 & 0.99 & 0.36 & 0.95 & 0.98 & 0.99 & 0.98 & 0.95 & & 0.98 & 1.00 & 0.98 \\
\hline $\mathrm{W}^{\mathrm{DB}}$ & 0.99 & 1.00 & 0.98 & 0.92 & 0.96 & 1.00 & 0.38 & 0.99 & 0.96 & 1.00 & 0.96 & 0.99 & 0.99 & & 0.96 & 0.99 \\
\hline $\mathrm{W}^{\mathrm{DC}}$ & 1.00 & 0.99 & 0.99 & 0.88 & 0.98 & 0.99 & 0.36 & 0.95 & 0.98 & 0.99 & 0.98 & 0.95 & 1.00 & 0.99 & & 0.96 \\
\hline
\end{tabular}

* The coefficients in bold are the pairwise correlation coefficients while the coefficients in times new roman font are spearman correlation coefficients.

Table 9 above gives the Pairwise and Spearman rank correlation coefficients of the attainment indices for the 8 idealized response matrices. The Spearman correlation coefficients (non-parametric correlation) talks about consistency in the ordering of attainment scores while pairwise correlation coefficient (parametric correlation) measures the strength of the linear relationship between the scores. The result shows that, for both the Spearman and Pairwise correlation coefficients, most of their values are high between zero and one, and are also highly significant $(p<0.01)$. The suggested conclusion, therefore, is that there is a considerable and reasonable degree of robustness and confidence in the results obtained for the various indices (supply and demand weight used), provided those variations are over a realistic range.

\section{Conclusion and Recommendation}

The study focused on matching farmers' perception on climate change characteristic to their effects on yam based production in Edo state, Nigeria. The empirical findings revealed that most of the farmers in the study area were aware that temperature and wind intensity are increasing and the level of precipitation is declining. The study presented an internally consistent approach to the evaluation of farmers' perception on climate change by quantifying the qualitative characteristics and the effects of these changes on yam production by presenting them on an ordinal scale as well as matching of the two characteristics. These have been shown to be relatively simple to construct and applywhile retaining a high degree of robustness. Development and adoption of strategies, options and improved technologies play a critically importantrole in improving agricultural productivity. Adoption studies have consistently emphasized that for any choice that would be made by farmers, perception of the current situation and the anticipated situation play an important role. Hence, the methodology proposed by Reed et al. (1991) [13], permits one to move beyond this to include, in a quantitative manner, the perceptions of farmers about the characteristics of climate change observed and what they perceive to be the effect of these changes on yam production. This paper has shown that such perceptions are critically important in influencing community, state and national decision. Perception of any attribute is based on feeling which is not quantifiable on an ordinal scale. The use of the method analysed in this paper can be incorporated in researches that will better the life of farmers.

Quantifying farmers' perceptions in the manner suggested in the paper potentially makes the method more palatable to station-based researchers used to cardinal types of analysis. As revealed by the study, the sharp increase and decrease in temperature and rainfall (two important climatic factors in crop production) respectively; are indications that climate change would have contributed significantly to reduction in yam production in the study area; this situation therefore creates the need for programmes or efforts geared towards providing farmers with effective adaptation strategies which would help provide a buffer against adverse climatic conditions. 


\section{Appendix}

\section{Appendix 1}

Table A1. Response Matrix Showing Perception of Farmers to Wind Intensity.

\begin{tabular}{lllll}
\hline \multirow{2}{*}{ Perceived Effect } & \multicolumn{2}{l}{ Observed Change in Wind Intensity } & Decrease & Row Total \\
\cline { 2 - 5 } & Increase & Constant & 12 & 45 \\
\hline Very severe & 29 & 4 & 22 & 89 \\
Severe & 49 & 18 & 23 & 116 \\
Not severe & 65 & 28 & 57 & 250 \\
Column total & 143 & 50 & 57 & \\
\hline
\end{tabular}

Source: Computed from field survey, May - June 2012

\section{Appendix 2}

Table A2. Response Matrix Showing Perception of Farmers to Temperature.

\begin{tabular}{lllll}
\hline \multirow{2}{*}{ Perceived Effect } & \multicolumn{2}{l}{ Observed Change in Air Temperature } & Decrease & Row Total \\
\cline { 2 - 5 } & Increase & Constant & 3 & 62 \\
\hline Very severe & 49 & 10 & 14 & 110 \\
Severe & 85 & 11 & 6 & 78 \\
Not severe & 62 & 10 & 23 & 250 \\
Column total & 196 & 31 & & \\
\hline
\end{tabular}

Source: Computed from field survey, May - June 2012

\section{Appendix 3}

Table A3. Response Matrix Showing Perception of Farmers to Rainfall.

\begin{tabular}{lllll}
\hline \multirow{2}{*}{ Perceived Effect } & \multicolumn{2}{l}{ Observed Change in Rainfall } & Decrease & Row Total \\
\cline { 2 - 5 } & Increase & Constant & 56 & 81 \\
\hline Very severe & 17 & 8 & 43 & 61 \\
Severe & 11 & 7 & 70 & 108 \\
Not severe & 19 & 19 & 169 & 250 \\
Column total & 47 & 34 & & \\
\hline
\end{tabular}

Source: Computed from field survey, May - June 2012

\section{Appendix 4}

Table A4. Weighting Matrix for Temperature.

\begin{tabular}{lllll}
\hline Perceived Effect & Increase & Constant & Decrease & Supply weight \\
\hline Very severe & 20 & 10 & 5 & $\mathrm{~s}_{1}=5$ \\
Severe & 4 & 2 & 1 & $\mathrm{~s}_{2}=1$ \\
Not severe & -4 & -2 & -1 & $\mathrm{~s}_{3}=-1$ \\
Demand weight & $\mathrm{d}_{1}=4$ & $\mathrm{~d}_{2}=2$ & $\mathrm{~d}_{3}=1$ & \\
\hline
\end{tabular}

Source: Computed from field survey, May - June 2012

\section{Appendix 5}

Table A5. Temperature Weighting Matrix Test I.

\begin{tabular}{lllll}
\hline Perceived Effect & Increase & Constant & Decrease & Supply weight \\
\hline Very severe & 12 & 9 & 6 & $\mathrm{~s}_{1}=3$ \\
Severe & 4 & 3 & 2 & $\mathrm{~s}_{2}=1$ \\
Not severe & -4 & -3 & -2 & $\mathrm{~s}_{3}=-1$ \\
Demand weight & $\mathrm{d}_{1}=4$ & $\mathrm{~d}_{2}=3$ & $\mathrm{~d}_{3}=2$ & \\
\hline
\end{tabular}

Source: Computed from field Survey, May - June 2012 


\section{Appendix 6}

Table A6. Temperature Weighting Matrix Test II.

\begin{tabular}{lllll}
\hline Perceived Effect & Increase & Constant & Decrease & Supply weight \\
\hline Very severe & 30 & 24 & 12 & $\mathrm{~s}_{1}=6$ \\
Severe & 10 & 8 & 4 & $\mathrm{~s}_{2}=2$ \\
Not severe & -5 & -4 & -2 & $\mathrm{~s}_{3}=-1$ \\
Demand weight & $\mathrm{d}_{1}=5$ & $\mathrm{~d}_{2}=4$ & $\mathrm{~d}_{3}=2$ & \\
\hline
\end{tabular}

Source: Computed from field survey, May - June 2012

\section{Appendix 7}

Table A7. Weighting Matrix for Precipitation.

\begin{tabular}{lllll}
\hline Perceived Effect & Increase & Constant & Decrease & Supply weight \\
\hline Very severe & 30 & 12 & 6 & 1 \\
Severe & 5 & 2 & -4 & -2 \\
Not severe & -10 & $\mathrm{~s}_{1}=6$ & 1 \\
Demand weight & $\mathrm{d}_{1}=5$ & $\mathrm{~d}_{2}=2$ & $\mathrm{~d}_{3}=1$ & $\mathrm{~s}_{3}=-2$ \\
\hline
\end{tabular}

Source: Computed from field survey, May - June 2012

\section{Appendix 8}

Table A8. Precipitation Weighting Matrix Test I.

\begin{tabular}{lllll}
\hline Perceived Effect & Increase & Constant & Decrease & Supply weight \\
\hline Very severe & 20 & 10 & 5 & 1 \\
Severe & 4 & 2 & $\mathrm{~s}_{1}=5$ & $\mathrm{~s}_{2}=1$ \\
Not severe & -4 & -2 & -1 & $\mathrm{~d}_{3}=1$ \\
Demand weight & $\mathrm{d}_{1}=4$ & $\mathrm{~d}_{2}=2$ & $\mathrm{~s}_{3}=-1$ & \\
\hline
\end{tabular}

Source: Computed from field survey, May - June 2012

\section{Appendix 9}

Table A9. Precipitation Weighting Matrix Test II.

\begin{tabular}{lllll}
\hline Perceived Effect & Increase & Constant & Decrease & \\
\hline Very severe & 24 & 12 & 6 & \\
Severe & 4 & 3 & 2 & $\mathrm{~s}_{1}=6$ \\
Not severe & -12 & -4 & -2 & $\mathrm{~s}_{2}=1$ \\
Demand weight & $\mathrm{d}_{1}=4$ & $\mathrm{~d}_{2}=3$ & $\mathrm{~d}_{3}=2$ & $\mathrm{~s}_{3}=-2$ \\
\hline
\end{tabular}

Source: Computed from field survey, May - June 2012

\section{Appendix 10}

Table A10. Weighting Matrix for Wind Intensity.

\begin{tabular}{lllll}
\hline Perceived Effect & Increase & Constant & Decrease & \\
\hline Very severe & 12 & 9 & 6 & \\
Severe & 4 & 3 & 2 & $\mathrm{~s}_{1}=3$ \\
Not severe & -4 & -3 & -2 & $\mathrm{~s}_{2}=1$ \\
Demand weight & $\mathrm{d}_{1}=4$ & $\mathrm{~d}_{2}=3$ & $\mathrm{~d}_{3}=2$ & $\mathrm{~s}_{3}=-1$ \\
\hline
\end{tabular}

Source: Computed from field survey, May - June 2012

\section{Appendix 11}

Table A11. Wind Intensity Weighting Matrix Test I.

\begin{tabular}{|c|c|c|c|c|}
\hline Perceived Effect & Increase & Constant & Decrease & Supply weight \\
\hline Very severe & 24 & 12 & 6 & $s_{1}=6$ \\
\hline Severe & 4 & 2 & 1 & $\mathrm{~S}_{2}=1$ \\
\hline Not severe & -8 & -4 & -1 & \\
\hline Demand weight & $\mathrm{d}_{1=4}$ & $\mathrm{~d}_{2=2}$ & $\mathrm{~d}_{3=} 1$ & $S_{3}=-2$ \\
\hline
\end{tabular}

Source: Computed from field survey, May - June 2012 


\section{Appendix 12}

Table A12. Wind Intensity Weighting Matrix Test II.

\begin{tabular}{lllll}
\hline Perceived Effect & Increase & Constant & Decrease & Supply weight \\
\hline Very severe & 30 & 24 & 12 & $\mathrm{~s}_{1}=6$ \\
Severe & 10 & 8 & 4 & $\mathrm{~s}_{2}=2$ \\
Not severe & -5 & -4 & -2 & $\mathrm{~s}_{3}=-1$ \\
Demand weight & $\mathrm{d}_{1}=5$ & $\mathrm{~d}_{2}=4$ & $\mathrm{~d}_{3}=2$ & \\
\hline
\end{tabular}

Source: Computed from field survey, May - June 2012

Fictive Data Used in Robustness Analysis.

\section{Appendix 13}

Table A13. Three by three (3 $x$ 3) idealized response matrix for experiment 1.

\begin{tabular}{lllll}
\hline Experiment 1 & Perception on climatic Characteristics & & Total \\
\hline Perception of the Effect & $\mathbf{1}$ & $\mathbf{2}$ & $\mathbf{3}$ & 0 \\
\hline 1 & 0 & 0 & 0 & 0 \\
2 & 0 & 250 & 0 & 0 \\
3 & 0 & 0 & 0 & 250 \\
Total & 0 & 250 & 0 & 0 \\
\hline
\end{tabular}

Source: Computed from field survey, May - June 2012

\section{Appendix 14}

Table A14. Three by three (3x 3) idealized response matrix for experiment 2.

\begin{tabular}{lllll}
\hline Experiment 2 & Perception on Climatic Characteristics & & Total \\
\hline Perception of the Effect & $\mathbf{2}$ & $\mathbf{2}$ & $\mathbf{3}$ & 250 \\
\hline 1 & 0 & 250 & 0 & 0 \\
2 & 0 & 0 & 0 & 0 \\
3 & 0 & 0 & 0 & 250 \\
Total & 0 & 250 & 0 & \\
\hline
\end{tabular}

Source: Computed from field survey, May - June 2012

\section{Appendix 15}

Table A15. Three by three ( $3 x$ 3) idealized response matrix for experiment 3.

\begin{tabular}{lllll}
\hline Experiment 3 & Perception on climatic Characteristics & & Total \\
\hline Perception of the Effect & $\mathbf{1}$ & $\mathbf{2}$ & $\mathbf{3}$ & 250 \\
\hline 1 & 0 & 0 & 250 & 0 \\
2 & 0 & 0 & 0 & 0 \\
3 & 0 & 0 & 0 & 250 \\
Total & 0 & 0 & 250 & 0 \\
\hline
\end{tabular}

Source: Computed from field survey, May - June 2012

\section{Appendix 16}

Table A16. Three by three ( $3 x$ 3) idealized response matrix for experiment 4.

\begin{tabular}{lllll}
\hline Experiment 4 & Perception on climatic Characteristics & & Total \\
\hline Perception of the Effect & $\mathbf{2}$ & $\mathbf{2}$ & $\mathbf{3}$ & 0 \\
\hline 1 & 0 & 0 & 0 & 250 \\
2 & 250 & 0 & 0 & 0 \\
3 & 0 & 0 & 0 & 250 \\
Total & 250 & 0 & 0 & \\
\hline
\end{tabular}

Source: Computed from field survey, May - June 2012 


\section{Appendix 17}

Table A17. Three by three ( $3 x$ 3) idealized response matrix for experiment 5 .

\begin{tabular}{lllll}
\hline Experiment 5 & Perception on climatic Characteristics & & Total \\
\hline Perception of the Effect & $\mathbf{1}$ & $\mathbf{2}$ & $\mathbf{3}$ & 250 \\
\hline 1 & 125 & 125 & 0 & 0 \\
2 & 0 & 0 & 0 & 0 \\
3 & 0 & 0 & 0 & 250 \\
Total & 125 & 125 & 0 & \\
\hline
\end{tabular}

Source: Computed from field survey, May - June 2012

\section{Appendix 18}

Table A18. Three by three $(3 x$ 3) idealized response matrix for experiment 6.

\begin{tabular}{|c|c|c|c|c|}
\hline \multirow{2}{*}{$\begin{array}{l}\text { Experiment } 6 \\
\text { Perception of the Effect }\end{array}$} & \multicolumn{4}{|c|}{ Perception on climatic Characteristics } \\
\hline & 1 & 2 & 3 & Total \\
\hline 1 & 125 & 0 & 125 & 250 \\
\hline 2 & 0 & 0 & 0 & 0 \\
\hline 3 & 0 & 0 & 0 & 0 \\
\hline Total & 125 & 0 & 125 & 250 \\
\hline
\end{tabular}

Source: Computed from field survey, May - June 2012

\section{Appendix 19}

Table A19. Three by three (3 $x$ 3) idealized response matrix for experiment 7 .

\begin{tabular}{lllll}
\hline Experiment 7 & Perception on climatic Characteristics & & \\
\hline Perception of the Effect & $\mathbf{1}$ & $\mathbf{2}$ & $\mathbf{3}$ & \\
\hline 1 & 0 & 0 & 0 & 100 \\
2 & 100 & 50 & 0 & 250 \\
3 & 0 & 0 & 0 & 100 \\
Total & 100 & 0 & 250 \\
\hline
\end{tabular}

Source: Computed from field survey, May - June 2012

\section{Appendix 20}

Table A20. Three by three $(3 \times 3)$ idealized response matrix for experiment 8.

\begin{tabular}{lllll}
\hline Experiment 8 & Perception on climatic Characteristics & \\
\hline Perception of the Effect & $\mathbf{1}$ & $\mathbf{2}$ & $\mathbf{3}$ & \\
\hline 1 & 0 & 0 & 0 & 0 \\
2 & 0 & 0 & 0 & 0 \\
3 & 100 & 50 & 100 & 0 \\
Total & 100 & 50 & 0 & 100 \\
\hline
\end{tabular}

Source: Computed from field survey, May - June 2012

\section{References}

[1] Adeniyi, S. (2012). Tuesday Tribune; April 10, 2012 Bill Gates inject \$ 12.2 in Nigeria, Ghana experts converge on IITA for action

[2] Agboola T, Ojeleye D (2007). Climate change and food production in Ibadan, Nigeria. Afr. Crop Sci. Confer. Proc., 8: 1423-1433.

[3] Central Bank of Nigeria (CBN), 2003: Statistical Bulletin, Publication of CBN, Nigeria

[4] Central Bank of Nigeria (CBN), 2004: Statistical Bulletin,
Publication of CBN, Nigeria Demographic and Health Survey, 2003. Publication of the Federal Government of Nigeria

[5] Central Bank of Nigeria (CBN), 2002: Statistical Bulletin, Publication of CBN, Nigeria

[6] Food and Agricultural Organization (FAO) of the United Nations, (1999). The state of food security in the world. Rome: FAO

[7] IPCC (2001). 'Climate Change 2001: Impacts, Adaptations and Vulnerabilities'. Contribution of Working Group II to the Third Assessment Report of the IPCC. New York; Cambridge University Press.

[8] IPCC (2007). Contribution of working Group II to the Fourth Assessment Report of the IPCC - Summary for Policy Makers. Retrieved March 8, 2010 from http://www.ipcc.ch: 
[9] IPCC, (1990): Climate Change: The IPCC Scientific Assessment [Houghton, J. T., G. J. Jenkins, and J. J. Ephraums (eds.)]. Cambridge University Press, Cambridge, United Kingdom and New York, NY, USA.

[10] Maddison, D. (2006). "The perception of and adaptation to climate change in Africa." CEEPA. Discussion Paper No. 10. Centre for Environmental Economics and Policy in Africa. Pretoria, South Africa: University of Pretoria.

[11] Nhemachena C., and Hassan, R. (2007). Micro-Level Analysis of Farmers' Adaptation to Climate Change in Southern Africa. IFPRI Discussion Paper No. 00714. International Food Policy Research Institute. Washington DC.
[12] Parry, M., Fischer, C., Livermore, M., Rosenzweig, C., and Iglesias, A.,(1999). Climate change and world food security: A new assessment. Global Environmental Change, 9: S51-S67.

[13] Reed, G. V., Binks, M. R., Ennew, C. T., (1991). "Matching the characteristics of a service to the preferences of customers." Managerial and Decision Economics 12, $231 \pm 240$

[14] Sofoluwe, N. A. Tijani, A. A, and Baruwa O. I (2011). "Farmers' perception and adaptation to climate change in Osun State, Nigeria." African Journal of Agricultural Research. Vol. 6 (20), pp. 4789-4794, Available online at http://www.academicjournals.org/AJARISSN 1991-637X (C)2011 Academic Journals. 